\title{
Gastrointestinal helminths found in the three freshwater turtles (Erymnochelys madagascariensis, Pelomedusa subrufa and Pelusios castanoides) from Ankarafantsika National Park, Madagascar
}

\author{
V. ROCA ${ }^{1}$, G. GARCÍA ${ }^{2}$, A. MONTESINOS ${ }^{1}$ \\ ${ }^{1}$ Departament de Zoología, Facultat de Ciències Biològiques, Universitat de València. Dr. Moliner, 50. 46100 \\ Burjassot, València (Spain), E-mail: Vicente.roca@uv.es; ${ }^{2}$ Durrell Wildlife Conservation Trust, Les Augrés Manor, \\ Jersey JE3 5BP. Channel Islands, British Isles (UK), E-mail: Gerardo.Garcia@durrell.org
}

\begin{abstract}
Summary
We conducted a survey of the presence, prevalence and diversity of gastrointestinal helminths in faecal samples and stomach contents of three turtle species, - Erymnochelys madagascariensis (Chelonia: Podocnemididae), Pelomedusa subrufa and Pelusios castanoides (Chelonia: Pelomedusidae), - from several localities in Madagascar. Four nematode species were detected: Atractis chabaudi, Camallanus chelonius, Falcaustra pelusios, and Spiroxys sp. E. madagascariensis, with all four species, had the greatest helminth diversity. A. chabaudi was the community's core species, whereas Spiroxys sp. was a satellite species. Only two species (A. chabaudi and Spiroxys sp.) were found in $P$. subrufa and only one, Spiroxys sp., in P. castanoides. These are the first helminthological data on E. madagascariensis, one of the most threatened freshwater turtles in the world.
\end{abstract}

Key words: turtles; nematodes; Madagascar

\section{Introduction}

Madagascar, with its high levels of species endemism, is considered a global hotspot of high conservational importance (García, 2005). Four species of freshwater turtles are found there: Pelomedusa subrufa, Pelusios castanoides, $P$. subniger (Pelomedusidae) and Erymnochelys madagascariensis (Podocnemididae) (Glaw \& Vences, 1994). Erymnochelys is a monotypic genus endemic to Madagascar (Bonm et al., 2006). It is a relict form of the fauna of Gondwana, and the only extant Old World representative of the family Podocnemididae. With populations in severe decline (García, 2005), it is one of the 15 chelonian species with the highest conservation priority rating in the IUCN/ SSC.

Previously there had been no studies on the helminth fauna of E. madagascariensis, and only a few partial studies of
P. subrufa and P. castanoides from Madagascar (Euzet \& Combes, 1965). In this paper, we report the helminths found in the gastrointestinal tracts of these hosts. Our approach was to analyse the prevalence, intensity, and diversity of their helminths specifically addressing the following points: (i) characterisation of taxonomy and chorology of the helminths; (ii) characterisation of the helminths as either specialists or generalists; and (iii) characterisation of the helminths as core, secondary or satellite species in the helminth community of E. madagascariensis.

\section{Material and Methods}

Study sites

The area where the sample was carried out was The Ankarafantsika National Park, in NW Madagascar, between the Marovoay and Ambato-Boeni regions in Mahajanga province $\left(16^{\circ} 00-16^{\circ} 20^{\prime} \mathrm{S}, 4^{\circ} 15^{\prime}-49^{\circ} 91^{\prime} \mathrm{E}\right)$ (Fig. 1). Nine sites were selected, including three lakes (Antsilomba, Ravelobe and Antsiloky), two rivers (Andranomiditra and Ambavan'Ampijoroa River) and an area modified by human activity, Ambarindahy.

\section{Sampling of hosts}

Three techniques for capturing turtles were used: trapping, netting, and fishing rods.

Baited traps have the advantage of not requiring much maintenance, apart from changing the bait. The major disadvantage is that they require regular checking since turtles may escape. The traps used were designed, described and built by Kuchling (2004).

In rivers, long nets were also used. No netting was possible in the lakes because it was culturally prohibited. Nets were used to trawl for turtles and were especially useful under aquatic vegetation along riverbanks.

Indirect capture through incidental collection by villagers 
during routine fishing excursions occurred in some areas using a number of traditional fishing techniques (see García, 2005). These incidental captures provided a source of turtles additional to direct trapping.

\section{Obtaining parasites}

The method of stomach flushing, described by Legler (1997), enabled the collection of animal and vegetable matter as well as nematodes in the stomach.

Faecal sampling is a good method to obtain parasites when examination of the intestine by sacrificing animals is not possible (Roca et al., 1999). We did not use destructive sampling because of the highly-threatened status of $E$. madagascariensis and because alternative techniques were available.

Six samples from $P$. castanoides (stomach contents), 12 from $P$. subrufa (stomach contents) and 95 from E. madagascariensis (8 stomach contents, 87 faecal samples) were obtained.

Samples were fixed in $70 \%$ alcohol. Parasites were identified to species when possible and the number of individuals of each species was recorded.

The use of descriptive eco-parasitological terms follows Bush et al. (1997) and a prevalence of $10 \%$ was adopted as the lowest limit in identifying satellite species (Kennedy \& Bakke, 1989). Species with prevalences $10 \%<\mathrm{p}<30$ $\%$ were assigned as secondary species (Hanski, 1982; Roca, 1993). Species with a prevalence of $30 \%$ or higher were considered as core species (Roca, 1993).

\section{Results}

Four nematode species were found. All were in the gastrointestinal tract of E. madagascariensis; two were in the stomach of $P$. subrufa, and only one in the stomach of $P$. castanoides. The total number of nematode species, the site in which they were found, and the infection prevalence are shown in Table 1. Specimens were deposited in the HeIminthological Collection of the Department of Zoology, University of Valencia, Spain, accession numbers S3SA, S63SD, P75SB, P89SA, S91SA, P94SB, C24SB, C48SA, C52SA, C67SA, C112SA, C128SB, C141FA, C205SC, C209FA, C228SA, C239FA, C297FA, EF1 - EF95.

From a quantitative point of view, the most important nematode found was Atractis chabaudi Petter, 1966 (Atractidae) (Fig. 2). Monodelphic females with two or three lar- ge eggs and many larvae in the uterus were identified. Males had two unequal spicules, cuticular ornamentation formed by one ventral range of small plectanes, and 10 pairs of caudal papillae: 3 precloacal, 1 adcloacal, and 6 postcloacal pairs.

Four specimens, one male, one female and two larvae, of Camallanus chelonius Baker, 1983 (Camallanidae) were found. They showed a peculiar cephalic structure with buccal valves made up of $8-10$ cuticular ridges (Fig. 3A).

Seventy-one specimens of Falcaustra pelusios Baker, 1983 (Kathlaniidae) were found. They were characterised by the presence of a spherical oesophageal isthmus, the absence

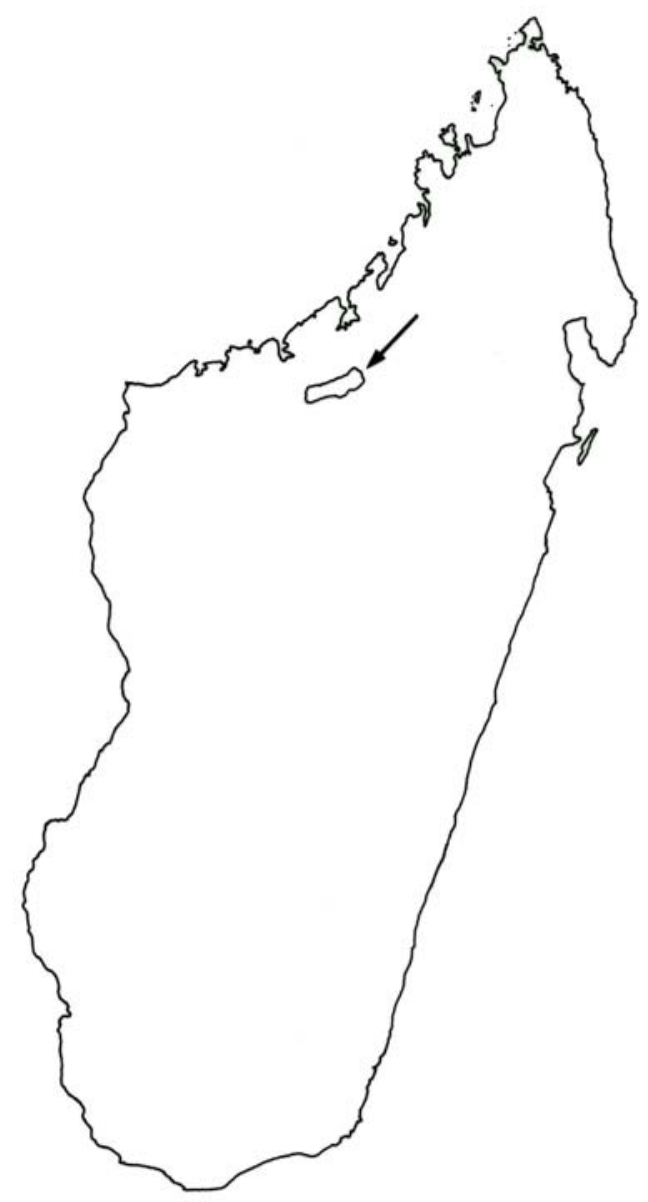

Fig. 1. Location (arrow) of Ankarafantsika National Park in Madagascar

Table 1. Nematode species and their prevalence, parasitising turtles from Madagascar

\begin{tabular}{|c|c|c|c|c|c|c|}
\hline \multirow[t]{2}{*}{ Species } & \multicolumn{3}{|c|}{ Site } & \multicolumn{3}{|c|}{ Prevalence (\%) } \\
\hline & E.m. & P.s. & P.c. & E.m. & P.s. & P.c. \\
\hline Atractis chabaudi & $\mathrm{FC}$ & $\mathrm{SC}$ & & 80 & 33.3 & \\
\hline Camallanus chelonius & $\mathrm{SC}$ & & & 3.2 & & \\
\hline Falcaustra pelusios & FC & & & 16.9 & & \\
\hline Spiroxys sp. & $\mathrm{SC}$ & $\mathrm{SC}$ & $\mathrm{SC}$ & 2.1 & 83.3 & 100 \\
\hline
\end{tabular}

E.m. - Erymnochelys madagascariensis; P.s. - Pelomedusa subrufa; P.c. - Pelusios castanoides; SC - stomach contents; FC - faecal sample 


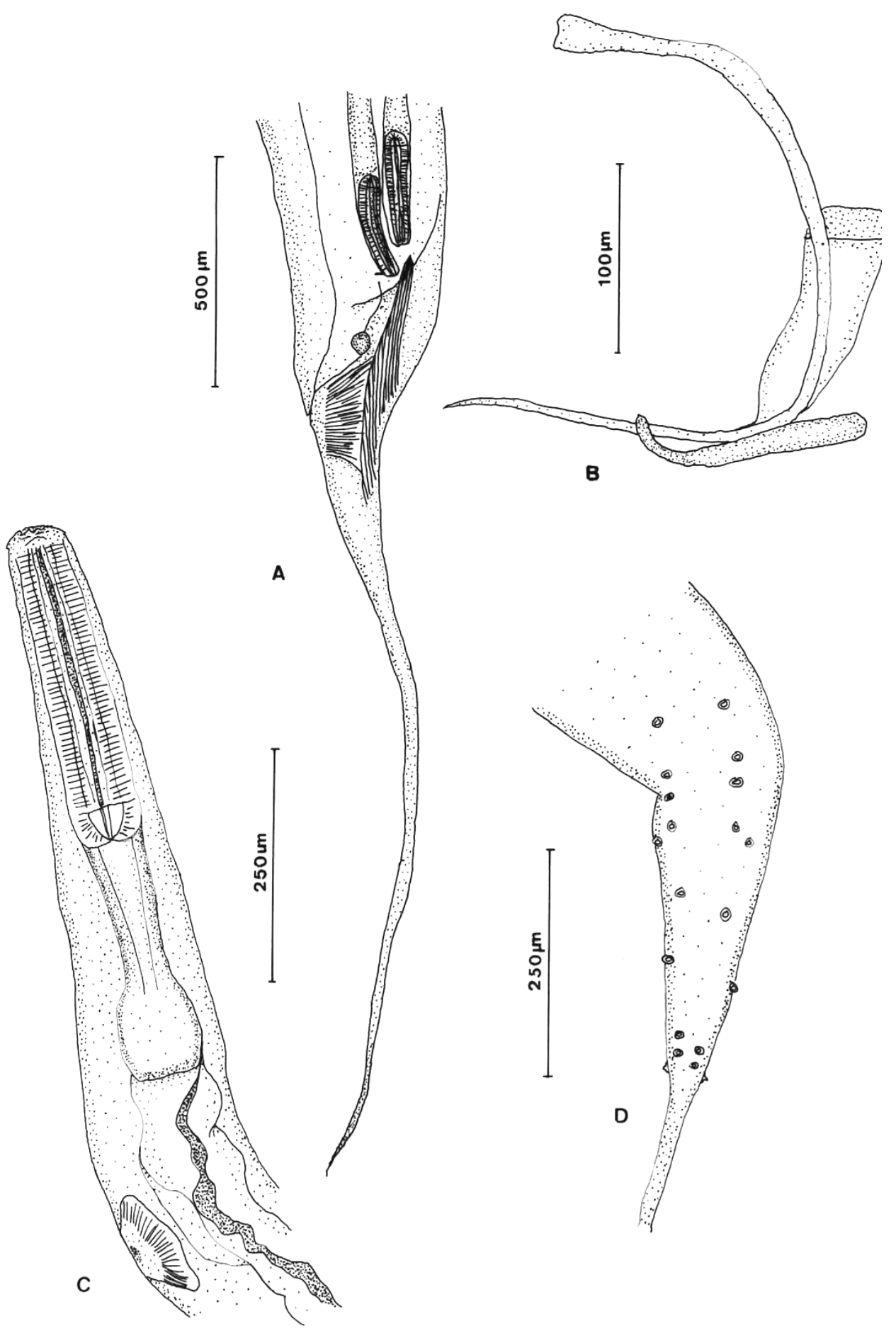

Fig. 2. Atractis chabaudi. A - $q$ caudal end, lateral view; $\mathrm{B}-$ spicules and gubernaculum; $\mathrm{C}-\uparrow$ anterior part of body, lateral view; $\mathrm{D}-\hat{\mathrm{O}}$ caudal end, ventral view. A - scale $500 \mu \mathrm{m}$; B - scale $100 \mu \mathrm{m}$; C, D - scale $250 \mu \mathrm{m}$

of an intestinal diverticulum, and, in the males, a pre-anal ventral sucker, two subequal spicules and a large gubernaculum (Fig. 3B, C, D).

A total of 34 specimens of Spiroxys sp. were found (14 males, 15 females, 5 larvae), mainly in $P$. subrufa and $P$. castanoides. The species is characterised by two large pseudolabia with denticulated lobes, no marked division between the anterior and posterior part of the oesophagus, non-larvated eggs in the females, and subequal spicules and ten pairs of caudal papillae in the males. 

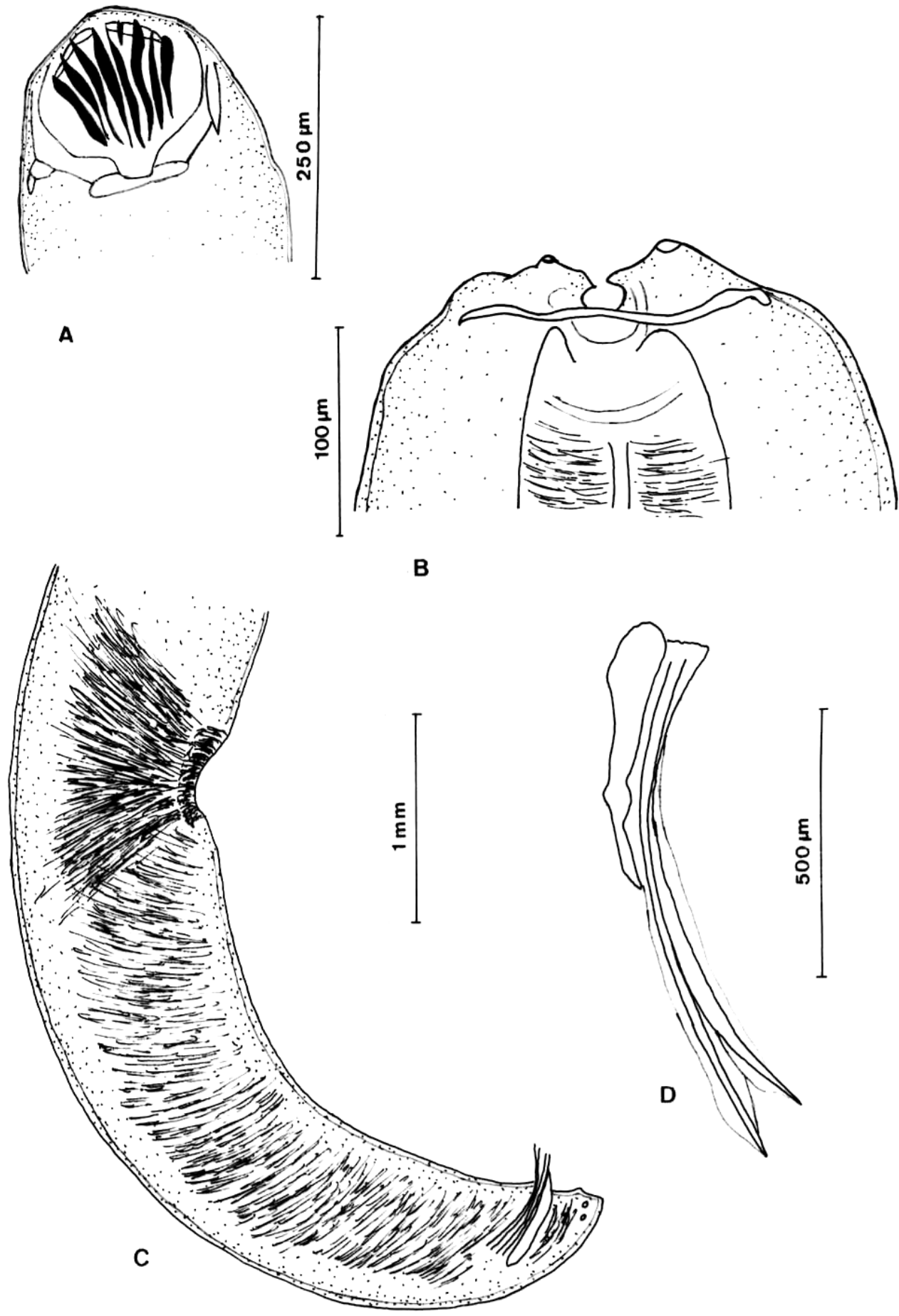

Fig. 3. A - Camallanus chelonius 9 anterior extremity, lateral view; $\mathrm{B}-$ Falcaustra pelusios 9 anterior extremity, dorsal view; $\mathrm{C}-$ Falcaustra pelusios ô posterior end, lateral view; D - Falcaustra pelusios, spicules and gubernaculum. A - scale $250 \mu \mathrm{m}$; B - scale $100 \mu \mathrm{m}$; C - scale $1 \mathrm{~mm}$; $\mathrm{D}$ - scale $500 \mu \mathrm{m}$

\section{Discussion}

Systematics and chorology of helminths

Atractis chabaudi is characterised by the morphology of the oesophagus; the length and morphology of the spicules (one of them long and lanceolate and the other short and 180 lagenoid); and the dispositon of caudal papillae in the males (Petter, 1966; Bursey \& Flanagan, 2002). With the same papillae pattern, our specimens match the original description of Petter (1966). This character separates A. chabaudi from the other Ethiopian species of the genus (Bursey \& Flanagan, 2002). A. chabaudi has been found in the 
tortoise Pyxis arachnoides (Testudinidae) from the south of Madagascar (Petter, 1966). Since we found it in freshwater turtles, we suggest that this species is a specialist (sensu Edwards \& Bush, 1989) for the group Testudinata (tortoises, terrapins, turtles) suggesting a co-adaptation and co-evolution among species of two ancient parasite-host groups, as the Atractidae (see Baker, 1982; Adamson \& Baccam, 1988) and the Testudinata (see Bellairs, 1969). The three species of turtles are new hosts for this nematode species.

With buccal valves each having 9 - 10 thick ridges (Baker, 1983), Camallanus chelonius is characterised by the morphology of its oral region. Our specimens had longitudinal ridges in the buccal valves undivided into dorsal and ventral groups, - a characteristic (division of the ridges) typical of the genus Serpinema (Yeh, 1960) - so they match the description by Baker (1983). Previously recorded from Pelusios sinuatus, this is the first record of this species in Madagascan turtles and corroborates the status of C. chelonius as an intermediate form in the evolution from Camallanus to Serpinema (see Petter, 1979; Baker, 1983). Serpinema first evolved in pleurodirans and later radiated with the major cryptodiran radiation around 120 - 90 mya (see Ferguson \& Smales, 1998).

Falcaustra Lane, 1915 (= Spironoura Leidy, 1856) contains many species with a worldwide distribution (Yamaguti, 1961; Manna \& Mahapatra, 1989). The specimens found in E. madagascariensis have been identified as $F$. pelusios by the presence of two cheilostomal rings at the cephalic extremity, the short tail in the male, subequal and thick spicules, large gubernaculum, and more than 50 pairs of subventral pre-anal muscle cells posterior to the sucker, features that match the description by Baker (1983) of specimens from Pelusios sinuatus. Another species, F. golvani Chabaud and Brygoo, 1957, was described in a rhacophorid frog in Madagascar, but it lacks a cheilostomal ring (Chabaud \& Brygoo, 1957). This is the first record of a Falcaustra species in E. madagascariensis, and the second in a pleurodiran turtle. Species of Falcaustra are much more common in cryptodirans (see Baker, 1983).

Most of the nematodes found in $P$. castanoides and $P$. subrufa had characteristics (see results) of the genus Spiroxys (see Yorke \& Maplestone, 1969; Chabaud, 1974). Studies on their specific identity are in progress (Roca, in preparation). This is the first record of Spiroxys sp. in Madagascan freshwater turtles. Confirmation of Spiroxys spp. in turtles in the Ethiopian region was only known previously from two male specimens labelled Spiroxys contorta from Pelusius subniger (Pelomedusidae) in Nigeria, deposited in the British Museum (Natural History, reg. $\mathrm{N}^{\circ}$ 1971.937) and confirmed as species of the genus (but not S. contortus) by Berry (1985).

This is also a new record of Spiroxys spp. in a pleurodiran turtle (previous records were in pleurodirans from Australia by Berry, 1985; Ferguson \& Smales, 1998), since Spiroxys spp. occur widely in the Cryptodira group. In accordance with the hypothesis of Berry (1985) regarding the presence of Spiroxys spp. in Australian pleurodiran turtles, we suggest that Ethiopian pleurodirans acquired Spiroxys from non-marine cryptodirans, perhaps from Palaearctic Bataguridae. This is supported by the presence of Spiroxys contortus and Spiroxys sp. in Mauremys leprosa (Bataguridae) from some areas of North Africa, Turkey, and the Iberian Peninsula (Schad et al., 1960; Yamaguti, 1961; Roca et al., 2005).

\section{Helminth communities}

Helminths occurred at moderate to low prevalence in the only representative in this sample, the host-species $E$. $m a$ dagascariensis. This is in line with the typical pattern of helminth infection in many reptiles, i. e., few species occur frequently, few species occur with moderate prevalence, and many species are rare (Aho, 1990; Roca et al., 2005). A. chabaudi can be considered as the core species (Table I). Its high prevalence might be related to the auto-infective cycle typical of the Atractidae, in which larvae hatch and develop to adulthood without passing to the external environment (Adamson \& Baccam, 1988). With a low prevalence, Spiroxys sp. is a satellite species in the helminth community of E. madagascariensis.

\section{References}

ADAMSON, M. L., BACCAM, D. (1988): Systematic revision of the Atractidae sensu Chabaud (1978) (Nematoda: Cosmocercoidea): Maracaya belemensis n. sp. and Aplectana albae n. sp. from Amphisbaena alba in Brazil. Can. J. Zool., 66: 1857 - 1864

AHO, J. M. (1990): Helminth communities of amphibians and reptiles: Comparative approaches to understanding patterns and processes. In EsCH, G., BusH, A. and AHO, J. M. (Eds): Parasite communities: patterns and processes. Chapman and Hall, London, pp. 157 - 195

BAKER, M. R. (1982): Systematic relationships of the Atractidae and Cosmocercidae (Nematoda: Cosmocercoidea): two new atractids parasitic in amphibians and fish. Can. J. Zool., 60: 2395 - 2402

BAKER, M. R. (1983): Nematode parasites of the turtle Pelusios sinuatus (Pelomedusidae: Pleurodira) from southern Africa. Syst. Parasitol., 5: 161 - 167

BELlairs, A. (1969): The life of Reptiles. Weidenfeld \& Nicolson, London

BERRY, G. N. (1985): A new species of the genus Spiroxys (Nematoda; Spiruroidea) from Australian chelonians of the genus Chelodina (Chelidae). Syst. Parasitol., 7: $59-68$ Bonm, F, Evaux, B., Dupre, A. (2006): Turtles of the world. The Johns Hopkins Press, Baltimore, Maryland. 313 pp.

Bursey, C. R., Flanagan, J. P. (2002): Atractis marquezi n. sp. (Nematoda: Atractidae) and a revision of Atractis Dujardin, 1845, sensu Baker, 1987. J. Parasitol., 88: 320 324

Bush, A. O., Laferty, K D., Loft, J. M., Shostak, A. W. (1997): Parasitology meets ecology on its own terms: Margolis et al. revisited. J. Parasitol., 83: 575 - 583

Chabaud, A. G. (1974): Keys to genera of the order Spi- 
rurida. In Anderson, R. C., Chabaud, A. G. and WillMOTT, S. (Eds): CIH Keys to the nematode parasites of vertebrates. Farnham Royal, Bucks: Commonwealth Agricultural Bureaux, pp. $1-58$

Chabaud, A. G., Brygoo, E. R. (1957): Deux nématodes, parasites de grenouilles à Madagascar: Falcaustra golvani n. sp. et Harentinema ambocaeca n. gen. n. sp. Ann. Parasitol. Hum. Comp., 32: 385 - 397

EDWARDS, D. D., Bush, A. O. (1989): Helminth communities in avocets: importance of compound community. $J$. Parasitol., 98: 439 - 445

Euzet, L., Combes, C. (1965): Parasites des Chéloniens malgaches. Polystomoides chabaudi n. sp. (Monogenea) chez la Tortue d'eau douce Pelomedusa subrufa Lacépède, 1788. Ann. Parasitol. Hum. Comp., 40: 445 - 450

Ferguson, M. A., SMAles, L. R. (1998): Spiroxys chelodinae Berry, 1985 (Nematoda: Spiruroidea) and Camallanus chelonius Baker, 1983 (Nematoda: Camallanoidea) from freshwater turtles (Pleurodira: Chelidae) in Queensland, Australia. Trans. Roy. Soc. South Aust., 122: 185 189

GARCíA, G. (2005): Ecology, human impact and conservation for the Madagascan side-necked turtle (Erymnochelys madagascariensis Grandidier, 1867) at Ankarafantsika National Park, Madagascar. PhD Thesis. University of DICE, Canterbury, Kent

GLAW, F., VENCES, M. (1994): A fieldguide to the amphibians and reptiles of Madagascar. Moos, Druck, Leverkusen and Farbo, Koln, Germany

HANSKI, I. (1982): Dynamics of regional distribution: the core and satellite species hypothesis. Oikos, 38:210 - 221

KENNEDY, C. R., BAKKE, T. A. (1989): Diversity patterns in helminth communities in common gulls, Larus canus. Parasitology, 98: 431 - 445
KuCHLING, G. (2004): A new underwater trap for catching turtles. Herp. Rev., 34: 126 - 128

LEGLER, J. M. (1997): Stomach flushing: a technique for chelonian dietary studies. Herpetologica, 33: $281-284$

MANNA, B., MAHAPATRA, M. S. (1989): Falcaustra bengalensis sp. nov. (Kathlaniidae: Nematoda) from a turtle Geoclemys hamiltoni (Gray, 1831). Indian J. Anim. Health, 1989: 133 - 137

PetTer, A. J. (1966): Équilibre des espèces dans les populations de nématodes parasites du colon des tortues terrestres. Mém. Mus. Nat. Hist. Nat. (sér. A, Zool.), 39: 1 252

PetTer, A. J. (1979): Essai de classification de la sous-famille des Camallaninae (Nematoda, Camallanidae). Bull. Mus. Nat. Hist. Nat. (sér. A, Zool.), 1: $991-1008$

RocA, V. (1993): Helmintofauna dels rèptils. Mon. Soc. Hist. Nat. Balears, 2: $273-292$

RocA, V., OrRit N., LlORENTE, G. (1999): Parasitofauna del lagarto gigante de El Hierro, Gallotia simonyi. Mon. Herpetol., 4: 127 - 137

RocA, V., SÁnchez-Torres, N., Martin, J. E. (2005): Intestinal helminths parasitizing Mauremys leprosa (Chelonia: Bataguridae) from Extremadura (western Spain). Rev. Esp. Herp., 19: $47-55$

Schad, G. A, Kuntz, R. E, Wells, W. H. (1960): Nematode parasites from Turkish vertebrates. An annotated list. Can. J. Zool., 38: 949 - 962

Yamaguti, S. (1961): Systema helminthum. Vol. III. The Nematodes of Vertebrates. Interscience Publishers, New York. $1261 \mathrm{pp}$ YoRKe, W., MAPLestone, P. A. (1969): The nematode parasites of vertebrates. Hafner Publishing Company, New York (second edition). $536 \mathrm{pp}$ 